ISSN: 2085-0344 (Print)

ISSN: 2503-1864 (Online)

Journal homepage: www.ejournal.almaata.ac.id/literasi

Journal Email: literasi_stia@yahoo.com

\title{
Pengaruh Metode Storytelling terhadap Penanaman Karakter Nasionalisme pada Siswa SD
}

\author{
Ruwet Rusiyono, An-Nisa Apriani \\ Program Studi Pendidikan Guru Sekolah Dasar, Universitas Alma Ata Yogyakarta \\ Jl. Brawijaya No. 99 Yogyakarta 55183 \\ Email: ruwet.rusiyono@almaata.ac.id
}

\begin{abstract}
Abstrak
Penelitian ini dilatarbelakangi oleh fenomena yang ada dalam dunia pendidikan saat ini yaitu semakin rendahnya nilai-nilai karakter nasinonalisme yang melekat pada diri siswa. Hal ini dikarenakan guru masih jarangyang menyisipkan nilai-nilai nasionalisme dalam kegiatan pembelajaran. Untuk itu perlu adanya cara yang tepat untuk memasukkan nilai-nilai karakter nasionalisme dalam pembelajaran mengunakan metode pembelajaran yang menarik sehingga dapat menciptakan antusiasme belajar siswa. Penelitian ini bertujuan untuk mengetahui pengaruh metode storytelling terhadap penanaman karakter nasionalisme pada siswa sekolah dasar. Penelitian ini menggunakan pendekatan kuantitatif dengan metode eksperimen. Subjek penelitiannya adalah siswa kelas V SD Negeri Ngebel, Kasihan, Bantul. Teknik pengumpulan data yang digunakan adalah wawancara, observasi dan dokumentasi. Berdasarkan hasil pengolahan data pre-test dan post-test maka dengan perhitungan ujit-t melalui program SPSS dengan hasil penanaman karakter nasionalisme pada anak yang dilakukan sebelum dan sesudah adanya pelakuan adalaht-hitung sebesar -11,393 dengan tingkat Sig. (2 tailed =0,000 jadi nilai t table sebesar -2,214 pada taraf Signifikansi $(\alpha=0,05)$, karena t-hitung $\geq t$ tabel. Berdasarkan hasil hitung tersebut dapat disimpulkan bahwa metode storytelling berpengaruh terhadap penanaman karakter nasionalisme pada anak.
\end{abstract}

Kata kunci : storytelling, penanaman karakter, nasionalisme

\begin{abstract}
This research is motivated by a phenomenon that exists in the world of education today, namely the lower values of national character inherent in students. This is because teachers still rarely insert nationalistic values in learning activities. For that we need the right way to incorporate the values of nationalism character in learning using interesting learning methods so as to create student enthusiasm for learning. This study aims to determine the effect of storytelling methods on the cultivation of nationalism in elementary school students. This research uses a quantitative approach with an experimental method. The research subjects were grade $V$ students of Ngebel Elementary School, Kasihan, Bantul. Data collection techniques used were interviews, observation and documentation. Based on the results of pre-test and post-test data processing, the t-test calculation through the SPSS program with the results of the inculcation of nationalism in children carried out before and after the treatment is a t-count of -11,393 with a Sig level, (2 tailed $=0,000$ so the t table value of -2,214 at the level of Significance $(\alpha=0.05)$, because $t$-count $\geq t$ table. Based on these results can be concluded that the storytelling method influences the planting of the character of nationalism in children.
\end{abstract}

Keywords: storytelling, planting characters, nationalism 


\section{PENDAHULUAN}

Pendidikan merupakan kebutuhan mendasar yang dibutuhkan oleh manusia. Hal itu didasari oleh sifat dasar manusia, dimana mereka selalu ingin mengetahui berbagi hal dalam kehidupan. Rasa keingintahuan itulah yang akan menstimulus manusia untuk terus belajar hingga dapat membentuk jati diri seseorang. Pembentukan jati diri manusia adalah tujuan dari pendidikan itu sendiri. Oleh karena itu, dapat diartikan tujuan pendidikan adalah membentuk manusia yang berkarakter dan berkualitas sehingga mempunyai pandangan yang lebih luas dalam rangka mencapai harapan yang diinginkan.

Tujuan pendidikan tersebut senada dengan undang-undang Sisdiknas No. 20 tahun 2003 Bab I, bahwa pendidikan adalah usaha sadar dan terencana untuk mewujudkan suasana belajar dan proses pembelajaran agar peserta didik secara aktif mengembangkan potensi dirinya untuk memiliki kekuatan spiritual keagamaan, pengendalian diri, kepribadian, kecerdasan, akhlak mulia, serta keterampilan yang diperlukan dirinya, masyarakat, bangsa dan negara ${ }^{1}$. Untuk merealisasikan pendidikan yang berkualitas membutuh upaya yang tidak mudah. Semua dalam pendidikan harus saling mendukung. Salah satu komponen dalam pendidikan yang berperan penting adalah lingkungan pendidikan.

Lingkungan pendidikan adalah segala sesuatu yang ada di sekitar manusia yang dapat dijadikan sumber untuk memperoleh pengetahuan. Lingkungan pendidikan mempunyai peran yang sangat penting. Hal itu cukup beralasan karena melalui lingkungan pendidikan, proses pendidikan akan berjalan. Proses pendidikan akan berjalan efektif jika didukung dengan suasana yang aman dan nyaman. Salah satu bentuk nyata lingkungan pendidikan yang mempunyai dampak signifikan dalam pemerolehan pendidikan yaitu lingkungan sekolah.

${ }^{1}$ Sofyan, Pendidikan Karakter dalam Perspektif Teori dan Praktik: Implementasi Pendidikan Karakter Melalui Kegiatan Mahasiswa. (Yogyakarta: UNY Press,110).
Lingkungan sekolah merupakan salah satu faktor yang turut mempengaruhi pertumbuhan dan perkembangan anak terutama untuk kecerdasannya ${ }^{2}$. Lingkungan sekolah yang baik akan menciptakan suasana pembelajaran yang nyaman dan menyenangkan. Lingkungan sekolah sangat berperan penting dalam membentuk karakter dan menumbuhkan pola pikir seorang anak. Tumbuhnya karakter dan pola berpikir anak berbanding lurus dengan perkembangan pendidikan khususnya ilmu pengetahuan dan teknologi/IPTEK.

Dewasa ini perkembangan IPTEK di lingkungan sekolah berkembang begitu pesat, bahkan mungkin sulit terbendung. Orang akan dengan cepat memperoleh informasi melalui media jejaring. Hal itu tentu mempunyai berdampak positif karena orang tidak perlu pergi jauh dan membutuhkan biaya yang besar untuk memperoleh informasi terbaru. Namun satu hal yang perlu kita kawatirkan adalah dampak negatif dari perkembangan teknologi itu sendiri. Saat ini sudah terlihat jelas bagaimana dampaknya bagi generasi muda Indonesia.

Generasi muda Indonesia yang dipersiapkan untuk membangun bangsa dan negara, kini sudah sudah kehilangan identitasnya. Rasa nasionalisme mereka terus menurun. Kecintaan akan tanah air Indonesia mulai luntur. Banyak di antara generasi muda yang dibanggakan terjerumus pada tindakantindakan yang mencoreng nilai-nilai luhur Pancasila. Nilai-nilai itu seperti gotong royong, persatuan, menghargai perbedaan dan lain sebagainya.

Nilai-nilai yang bertentangan dengan Pancasila dapat diidentifikasi dari rendahnya sikap nasionalisme pada generasi muda. Sikap nasionalisme mencakup cinta tanah air, menghargai jasa para pahlawan, rela berkorban demi bangsa, mengutamakan kepentingan umum, membina persatuan dan kesatuan, bangga pada budaya yang beraneka ragam, bangga sebagai bangsa Indonesia, sikap

${ }^{2}$ Dalyono, 2010. Psikologi Pendidikan. (Jakarta: Rieneka Cipta,131) 
toleransi, cinta terhadap lingkungan, dan bekerja sama ${ }^{3}$. Untuk itu perlu penanaman karakter nasionalisme pada generasi muda.

Istilah karakter diambil dari bahasa Yunani yang berarti to mark (menandai). Istilah ini lebih fokus pada tindakan atau tingkah laku. Secara etimologis, kata karakter berasal dari bahasa latin kharakter, kharassein, dan kharax yang maknanya "tools for marking", "to engrave", dan "pointed stake". Kata ini dimulai banyak digunakan pada abad ke-14 dalam bahasa Perancis caractere, kemudian masuk dalam bahasa inggris menjadi character dan akhirnya menjadi bahasa Indonesia karakter ${ }^{4}$.

Karakter adalah sebuah pola atau skema yang berupa pikiran, sikap atau tindakan yang melekat pada diri seseorang dengan sangat kuat dan tidak mudah untuk dihilangkan ${ }^{5}$. Karakter biasanya dipengaruhi oleh lingkungan dimana ia berada. Perilaku seseorang anak akan meniru lingkungan yang ia tempati. Sebagai contohnya, jika seorang anak berada dilingkungan yang religius, anak tersebut akan terpapar hal-hal yang religius pula. Oleh karena itu penanaman karakter harus dimulai sejak usia dini.

Melihat adanya kenyataan tersebut, mengindikasikan perlunya pengembangan karakter pada anak melalui pola asuh yang tepat oleh orangtua; tidak sekedar pengetahuan atau kecerdasan intelektual semata, tetapi juga menjangkau dalam wilayah moral atau kepribadian. Karakter memiliki sifat dua arah dimana arahannya adalah anak mampu memiliki ketajaman intelektual dan integritas diri sebagai pribadi yang memiliki karakter kuat ${ }^{6}$.

${ }^{3}$ Apriani, A.N., dan Ariyani, Y.D.. "Analisis Muatan Nilai-Nilai Nasionalisme Pada Buku Teks KTSP Pkn Kelas 3 SD”. Elementary School (Jurnal Pendidikan dan Pembelajaran Ke-SD-an), 4(2) (2017)

${ }^{4}$ Zaim Elmubarok, Membumikan Pendidikan Nilai. (Bandung: CV. Alfabeta. 2008, 102)

${ }^{5}$ Abdullah Munir. Pendidikan Karakter Membangun Karakter Anak Sejak dari Rumah. (Yogyakarta: PT Pustaka Insan Madani, 2010)

${ }^{6}$ Dony Koesoema, Pendidikan Karakter: Strategi Mendidik Anak di Zaman Global. Jakarta: PT. Grasindo, 2007, 112)
Sementara nasionalisme berasal dari kata nation yang berarti negara atau bangsa, di tambah akhiran isme berarti: Suatu sikap ingin mendirikan negara bagi bangsanya sesuai dengan paham/ideologinya. Suatu sikap ingin membela tanah air/negara dari penguasaan dan penjajahan bangsa asing ${ }^{7}$. Nasionalisme adalah perasaan satu sebagai suatu bangsa, satu dengan seluruh warga yang ada dalam masyarakat. Nasionalisme dapat diartikan sebagai kecintaan seseorang pada tanah airnya ${ }^{8}$.

Nasionalisme digunakan sebagai alat pemersatu oleh para pendiri bangsa ini adalah nasionalisme sebagai bentuk perwujudan dari nilai-nilai Pancasila, yaitu nasionalisme yang mentauladani sifat-sifat Tuhan, cinta akan keadilan, egaliter, dan menghargai hak asasi manusia. Rasa nasionalisme yang berdasarkan nilai-nilai Pancasila akan mewujudkan nasionalisme yang luas, yaitu mencintai bangsa sendiri tetapi masih menghargai bangsa lain".

Penanaman karakter nasionalisme penting dilakukan di sekolah karena lingkungan sekolah dasar adalah pijakan yang kuat dan penting dalam menumbuhkan norma, keyakinan, dan kebiasaan sehingga terbentuk karakter yang kuat untuk menghadapi kehidupan yang dinamis dan beragam. Untuk itu perlu adanya upaya penanaman karakter dengan mengintegrasikan nilai-nilai nasionalisme.

Penanaman karakter nasionalisme pada anak, khususnya untuk usia sekolah dasar tidak mudah dan memerlukan perhatian yang khusus. Dengan cara atau teknik yang tepatlah proses itu akan berjalan dengan baik. Penanaman karakter yang efektif adalah dengan cara pemberian contoh secara langsung. Anak akan lebih cepat mengadaptasi jika seorang anak melihat dan mencontoh secara langsung. Namun ada acara

\footnotetext{
${ }^{7}$ Kabul Budiyanto, Nilai-nilai Kepribadian Bangsa Indonesia ( Bandung: Alfabeta, 2007, 208)

${ }^{8}$ Rukiyati, dkk, Pendidikan Pancasila. (Yogyakarta: UNY Press. 2008, 69)

${ }^{9}$ Miftahuddin. Nasionalisme Indonesia: Nasionalisme Pancasila. Vol. 4 number 1, Januari 2008. Diakses di http://journal.uny.ac.id/index.php/ pada tanggal 03 Januari 2019 pukul 14.24 WIB.(2008)
} 
lain yang lebih efektif untuk menanamkan karakter pada anak, yaitu mengintegrasikan nilai-nilai karakter melalui proses pembelajaran, yaitu penggunaan metode storytelling. Kegiatan storytelling adalah proses pemberian informasi pada anak dengan cara yang menarik.

Metode storytelling merupakan suatu kegiatan yang dilakukan secara lisan kepada orang lain dengan alat atau tanpa alat yang disampaikan dalam bentuk pesan, informasi atau hanya sebuah dongeng yang untuk didengarkan dengan rasa menyenangkan, oleh karena orang yang menyajikan cerita tersebut menyampaikannya ${ }^{10}$. Penyajian storytelling akan mengisi memori anak dengan berbagai informasi termasuk nilai-nilai kehidupan dan berbagai sudut pandang. Peristiwa-peristiwa yang ada dalam cerita akan memperkaya pengalaman anak sehingga dapat digunakan sebagai bahan referensi pemecahan masalah atau mengubah perilaku.

Storytelling juga mampu membawa anak untuk menciptakan imajinasi dan fantasi terhadap cerita yang dibawakannya sehingga anak mampu berkreasi berdasarkan khayalan mereka. Apabila imajinasi anak tersebut diarahkan pada nilai-nilai karakter maka diharapkan anak tersebut memiliki kepribadian dan karakter yang baik. Model atau contoh, selain dapat diberikan melalui perilaku yang dilakukan secara nyata oleh orangtua, guru, maupun teman sebaya, juga dapat diberikan melalui dongeng ${ }^{11}$.

Metode storytelling merupakan metode pembelajaran yang dapat dikatakan sudah kuno, namun kebermanfaatannya masih cukup ampuh sampai saat ini. Bercerita adalah seni sastra kuno yang didalamnya terdapat alat pembelajaran nilai. Jadi bercerita merupakan bagian dari pembelajaran yang sarat mengandung muatan nilai-nilai yang baik. Dengan demikian,

${ }^{10}$ Astiti, N., Rukayah, \& Sularmi. Peningkatan Keterampilan Menyimak Dongeng melalui Metode Storytelling. (2016, 2).Diakses dari http://www.jurnal. fkip.uns.ac.id/index.p hp/

${ }^{11}$ Julita, D., Rubiantoro, Y., Susanto, T., \& Ahyar, R. F. Dongeng bentuk karakter anak. Warta PAUDNI, Tahun XV, edisi VII. (2012). kegiatan bercerita seorang guru akan lebih mudah dalam menanamkan pembelajaran nilai kepada siswa ${ }^{12}$.

Berdasarkan hasil wawancara dengan guru kelas V SD Negeri Ngebel Tamantirto, Kasihan Bantul. Penanaman karakter pada anak, khususnya karakter nasionalisme pada anak masih sangat rendah. Selama ini implementasi penanaman karakter nasionalisme anak masih hanya sebatas pada kegiatan-kegiatan ektrakulikuler sekolah. Peneliti menyakini bahwa penanaman karakter pada anak di SD Negeri Ngebel masih sangat kurang. Oleh karena itu perlu upaya yang nyata untuk menanamkan dan menumbuhkan semangat nasionalisme pada anak dengan mengintegrasikan dalam proses pembelajaran melalui metode storytelling.

Penelitian bertujuan ini menggunakan metode storytelling dengan media Buku Pembelajaran Tematik dan Pop Up Book yang telah diintegrasikan dengan karakter nasionalisme. Buku Pembelajaran Tematik dan Pop Up Book dikemas dengan tampilan menarik, penuh gambar dan menggunakan bahasa yang mudah diterima oleh anak usia sekolah dasar. Peneliti meyakini dengan metode dan media tersebut akan mampu menanamkan karakter nasionalisme pada anak. Jadi, penelitian ini bertujuan untuk mengetahui pengaruh penggunaan metode storytelling terhadap penanaman karakter nasionalisme siswa kelas V SD Negeri Ngebel Kasihan Bantul.

\section{METODE PENELITIAN}

Penelitian ini menggunakan PreExperimental Designs dengan model OneGroup Pretest-Posttest Design. Di dalam model ini sebelum mulai perlakuan kedua kelompok diberi tes awal atau pretest untuk mengukur kondisi awal (O1) selanjutnya diberi perlakuan (X) dan pada kelompok pembanding tidak diberi. Selesai perlakuan kedua kelompok diberi tes lagi sebagai posttest $(\mathrm{O} 2)^{13}$. Penelitian ini

${ }^{12}$ Ayuni, R.D., Siswati, \& Rusmawati, D. Pengaruh Storytelling Terhadap Perilaku Empati Anak. Jurnal Psikologi Undip, 12 (2), (2013. 121-130).

${ }^{13}$ Sugiyono, Metode Penelitian Kuantitatif, 
dimulai pada bulan Juli - Agustus 2018 Tahun Ajaran 2018/2019. Penelitian ini dilaksanakan di Kelas V SD Negeri Ngebel Tamantirto Kasihan Ngebel Bantul Daerah Istimewa Yogyakarta. Subjek penelitian merupakan siswa kelas VA dan VB SD Negeri Ngebel, Kasihan Bantul. Kelas VA berjumlah 23 siswa sebagai kelas kontrol, sedangkan kelas V B berjumlah 21 siswa sebagai kelas eksperimen.

Teknik pengumpulan data yang digunakan dalam penelitian ini adalah observasi, wawancara dan dokumentasi. Observasi adalah suatu teknik yang dilakukan untuk pengamatan dan pencetakan secara sistematis terhadap gejala yang tampak pada objek penelitian. Melalui observasi peneliti akan dapat melihat dengan jelas bagaimana kondisi nyata subjek penelitian ${ }^{14}$. Wawancara merupakan salah satu upaya untuk mengumpulkan data dalam rangka mendapatkan informasi perkembangan dan permasalahan anak melalui percakapan secara langsung ${ }^{15}$. Dokumentasi adalah suatu metode yang dilakukan untuk mencara data terkait segala sesaut yang berupa catatan buku, majalah, surat kabar dan lain sebagainya

Teknik analisis data yang digunakan menggunakan uji-t kasus satu sampel yang berguna untuk membandingkan atau menguji apakah ratarata populasi yang diduga/dihipotesiskan $(\mu 0)$ dapat diuji kebenarannya melalui rata-rata sampel yang diambil. Rumus Uji-t yang digunakan dalam penelitian ini adalah sebagai berikut.

$$
t=\frac{\bar{D}}{\left(\frac{S D}{\sqrt{N}}-\right)}
$$

Keterangan:

$\mathrm{t}$ : Nilai $\mathrm{t}$ hitung

$\square$ : Rata-rata selisih pengukuran $1 \& 2$

SD: Standar deviasi selisih pengukuran $1 \& 2$ $\mathrm{N}$ : Jumlah sampel

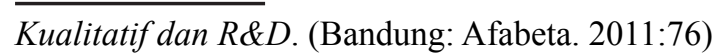

${ }^{14}$ Margono, Metodologi Penelitian Pendidikan. (Jakarta: PT. Rineka Cipta. S. 2005,158)

${ }^{15}$ Ernawulan Syaodih, Bimbingan di Taman KanakKanak. (Jakarta: Departemen Pendidikan Nasional, 2005,95)

\section{HASIL DAN PEMBAHASAN \\ Implementasi Nilai-Nilai Karakter Nasionalisme}

Penelitian ini pada siswa kelas V di SD Negeri Ngebel Kasihan Bantul dengan Kelas VA sebagai kelompok eksperimen, dan kelas VB sebagai kelompok kontrol. Tujuan penelitian ini adalah mengetahui pengaruh penggunaan metode storytelling terhadap penanaman karakter nasionalisme siswa kelas V SD. Karakter nasionailisme mencakup cinta tanah air, menghargai jasa para pahlawan, rela berkorban demi bangsa, mengutamakan kepentingan umum, membina persatuan dan kesatuan, bangga pada budaya yang beraneka ragam, bangga sebagai bangsa Indonesia, sikap toleransi, cinta terhadap lingkungan, dan bekerja sama Nilai-nilai nasionalisme secara spesifik belum diajarkan di sekolah dasar melalui poses pembelajaran. Sekarang masih dimasukkan dalam kegiatan-kegiatan ektrakulikuler seperti pramuka dan contoh sikap secara langsung yang dicontohkan oleh guru. Namun ada acara lain yang bisa dilakukan yaitu dengan metode storytelling. Metode storytelling merupakan metode pembelajaran efektif sederhana namun untuk diterapkan dalam proses pembelajaran masih cukup ampuh sampai saat ini. Jadi storytelling merupakan bagian dari pembelajaran yang sarat mengandung muatan nilai-nilai yang baik.

Penelitian ini berusaha mengetahui seberapa besar pengaruh metode storytelling terhadap nilai karakter nasionalisme. Bentuk dari nilai nasionalisme mencakup pengalaman nilai-nilai yang terdapat dalam Pancasila sebagai berikut: (1) Ketuhanan yang Maha Esa; (2) Kemanusiaan Yang Adil dan Beradab; (3) Persatuan Indonesia, (4) Kerakyatan yang Dipimpin oleh Hikmat Kebijaksanaan dalam Permusyawaratan Perwakilan; (5) Keadilan Sosial Bagi Seluruh Rakyat Indonesia.

Kelima sila itulah yang menjadi butirbutir yang diamati dalam penelitian yang dilakukan.

Proses pembelajaran karakter nasionalisme dalam penelitian ini menggunakan 
metode storytelling. Penanaman karakter nasinonalisme berjalan dengan baik karena didukung oleh guru dan penggunaan media yang sesuai sehingga memudahkan peserta didik memahami apa yang disampaikan oleh guru. Media aja yang digunakan adalah Buku Pembelajaran Tematik dan Pop Up Book. Melalui tampilan Buku Pembelajaran Tematik dan Pop Up Book yang menaik membuat peserta didik termotivasi untuk mendengarkan apa yang disampaikan oleh guru. Pada saat penelitian, guru menyampaikan materi aja dengan penuh penghayatan untuk menimbulkan kesan hidup dalam pembelajaran. Selain itu dalam pelaksanaannya guru juga menyampaikan storytelling dari media Buku Pembelajaran Tematik yang suda diintegrasikan dengan nilai-nilai karakter. Melalui buku Pembelajaran Tematik, siswa secara tidak langsung akan terpapar nilai-nilai karakter nasionalime yang mampu diterapkan dalam kehidupan sehari-hari.

Metode storytelling atau orang sering bilang metode mendongeng sangat berdampak signifikan dalam proses pembelajaran. Hal itu terlihat saat proses pembelajaran. Terlihat saat guru mendongeng, siswa seperti terhipnotis oleh guru, siswa diam mendengarkan. Kelas dengan menggunakan metode storytelling lebih terkesan hidup. Peserta didik diajak untuk ikut berpartisipasi dalam pembelajaran. Peserta didik juga diberikan kesempatan untuk berlatih menggunakan metode storytelling. Mereka diajak untuk menemukan nilai-nilai nasionalisme yang terdapat dalam cerita tersebut. Semua siswa masuk dalam dunia fiktif imajinatif yang ada dalam cerita guru. Pemberian cerita melalui metode storytelling tersebut secara tidak langsung akan terekam dan berpengaruh pada siswa.

Berdasarkan hasil pengamatan terlihat dari penanaman karakter nasionalisme yang pada diri siswa adalah sebagai berikut: (1) Ketuhanan yang Maha Esa. Siswa tampak lebih khusyuk dalam beribadah. Perubahan perilaku terlihat dengan jelas saat kegiatan pembelajaran akan dimulai. Tampak begitu khusyuk dan tenang dalam berdoa. Selain itu, untuk menumbuhkan rasa nasionalisme, guru juga mengajak siswa mendoakan arwah para pahlawan bangsa agar rasa nasionalisme mereka tetap tumbuh. Kepedulian siswa akan kesehatan semakin tinggi. Kesadaran siswa akan pentingnya kesehatan semakin tinggi. Pada saat pembelajaran menggunakan storytelling guru selalu menekankan pentingnya kesehatan, dan memberikan pengertian bahwa kesehatan adalah sebagian dari iman. Selain menjaga kesehatan sendiri, siswa diarahkan untuk ikut menjaga kesehatan lingkungan; (2) Kemanusiaan Yang Adil dan Beradab. Terbentuknya sikap kepedulian antara satu dengan yang lain. Implementasi dalam sila ke-2 dapat diwujudkan dalam bentuk kepedulian akan hak setiap orang untuk memperoleh lingkungan hidup yang baik dan sehat; hak setiap orang untuk mendapatkan informasi lingkungan hidup yang berkaitan dengan peran dalam pengelolaan lingkungan hidup; hak setiap orang untuk berperan dalam rangka pengelolaan lingkungan hidup yang sesuai dengan ketentuanketentuan hukum yang berlaku dan sebagainya ${ }^{16}$. Siswa lebih mengerti pentingnya kepedulian satu dengan yang lain. Terlihat saat pembelajaran ada seorang anak yang tidak membawa pena, dengan cepat salah satu siswa meminjamkan penanya. Hal itu dapat disimpulkan bahwa kepekaan siswa tumbuh dengan sangat baik. Tumbuhnya jiwa toleransi dan saling menghargai yang kuat antar siswa. Jika sebelumnya sering terjadi peundungan pada siswa. Sekarang siswa lebih paham dampat negatif dari perundungan yang tidak akan hilang sampai kapanpun. Mereka lebih mengerti arti penting dari menghargai dan toleransi antar sesama. (3) Persatuan Indonesia. Tumbuhnya semangat kebersamaan. Kebersamaan adalah salah satu indikator kesuksesan dalam pengamalan sila ke-3 dalam Pancasila. Melalui kebersamaan akan tumbuh sikap-sikap positif dalam diri siswa. Dalam pembelajaran melalui storytelling terlihat bagaimana perubahan

${ }^{16}$ Koesnadi Hardjasoemantri, 2000. Hukum TataLingkungan. (Yogyakarta: Gadjah Mada UniversityPress, 558 ) 
sikap siswa dalam kehidupan sehari-hari. Yang awal mula cenderung individualis, namun kini tampak lebih kompak dan saling membantu satu sama lain. Pengakuan kebinekatunggalikaan terbentuk dengan baik pada diri siswa. Dalam pembelajaran menggunakan storytelling terdapat nilai-nilai kebinekatunggalikaan yang disisipkan. Melalui nilai tersebut, siswa akan lebih memahami arti perbedaan dan bagaimana mensikapi perbedaan itu. Contoh konkrit yang nampak adalah saat beribadah ada salah satu siswa yang beragama Kristen. Mereka malah mengingatkan siswa yang lain untuk menunaikan ibadah shalat. Tumbuhnya sikap cinta tanah air pada diri masing-masing siswa. Kecintaan pada tanah air adalah sikap yang harus ditanamkan pada siswa sejak dari usia dini. Dengan tumbuhnya kecintaan pada tanah air secara tidak langsung tumbuh pula rasa nasionalisme pada siri masing-masing siswa. (4) Kerakyatan yang Dipimpin oleh Hikmat Kebijaksanaan dalam Permusyawaratan Perwakilan. Pengambilan keputusan dengan cara bermusyawarah. Musyawarah adalah suatu proses pengambilan keputusan yang dilakukan secara bersama yang didasarkan pada kepentingan bersama dan hasil dari keputusan bisa diterima dengan akan sehat sesuai dengan hati nurani. Bentuk konkret kegiatan musyawarah yang berjalan, misalnya saat pemilihan ketua kelas dan pelaksanaan kegiatan pembelajaran saat sesi berdiskusi. Mengutamakan kepentingan bersama dibanding kepentingan pribadi. Kepedulian siswa tumbuh dengan baik dengan adanya sikap mendahulukan kepentingan orang lain di atas kepentingan pribadi. Terlihat saat pemilihan perwakilan untuk ikut dalam kegiatan berlombaan kelas. Ada yang beberapa yang ingin sekali mengikuti lomba tersebut. Namun berdasarkan hasil keputusan bersama dan ada salah satu siswa yang mengundurkan diri karena memberi kesempatan teman yang lain agar bisa ikut serta dalam lomba tersebut. (5) Keadilan Sosial Bagi Seluruh Rakyat Indonesia. Tidak adanya sikap diskriminatif. Perlakuan yang adil di segala bidang kehidupan seharusnya bisa tertanam dalam diri para siswa. Melalui perlakuan adil tersebut akan menghilangkan sikap diskrimiatif yang sangat berbahaya jika sudah melekat dalam diri siswa. Dengan pembelajaran menggunakan metode storytelling, siswa diajak untuk bersikap dan berlaku ada antar satu dengan yang lainnya. Hal itu sudah tercermin dengan dalam keseharian siswa, dimana mereka kini tidak membeda-bedakan satu dengan yang lainnya. Memberikan bantuan pada siswa lain yang membutuhkan. Semangat untuk saling membantu adalah salah satu kunci keberhasilan dalam membangun pondasi suatu bangsa. Hal itulah yang diingin diperkuat dalam upaya untuk menumbuhakan rasa nasionalisme melalui kebersamaan. Dengan kebersamaan pekerjaan akan menjadi lebih mudah. Wujud nyata terlihat dari siswa yan kini dalam melakukan aktivitas didasari dengan kebersamaan, sperti ketika ada siswa yang sedang terkena musibah. Siswasiswa bahu membahu mengumpulkan uang saku mereka untuk kumpulkan dan disumbangkan pada teman yang membutuhkan.

\section{Pengaruh Signifikan Metode Storytelling terhadap Penanaman Karakter Nasionalisme pada Anak}

Berdasarkan hasil pengolahan data pretest dan post-test maka dengan perhitungan ujit-t melalui program SPSS dengan hasil penanaman karakter nasionalisme pada anak yang dilakukan sebelum dan sesudah adanya pelakuan adalah t-hitung sebesar -11,393 dengan tingkat Sig, (2 tailed $=0,000$ jadi nilai $\mathrm{t}$ table sebesar $-2,214$ pada taraf Signifikansi $(\alpha=0,05)$, karena $\mathrm{t}$-hitung $\geq \mathrm{t}$ tabel. Berdasarkan hasil hitung tersebut dapat ditarik kesimpulan bahwa metode storytelling berpengaruh terhadap penanaman karakter nasionalisme pada anak.

Peneliti menyimpulkan bahwa penanaman karakter nasionalisme pada anak sebelum menggunakan storytelling terlihat masih sangat rendah, hal itu senada dengan pengujian saja dilakukan pada tahap pre-test. Hal itu terlihat saat kegiatan pembelajaran, rasa kebersamaan siswa masih sangat kurang, jiwa toleransi juga belum terbentuk dengan baik pada diri 
Tabel. 1 Paired Sample Test

\begin{tabular}{|c|c|c|c|c|c|c|c|c|}
\hline & \multicolumn{5}{|c|}{ Paired Diffences } & \multirow{3}{*}{$\mathrm{t}$} & \multirow{3}{*}{$\mathrm{df}$} & \multirow{3}{*}{$\begin{array}{c}\text { Sig. } \\
\text { (2-talied) }\end{array}$} \\
\hline & \multirow{2}{*}{ Mean } & \multirow{2}{*}{ Std. Deviation } & \multirow{2}{*}{$\begin{array}{l}\text { Std. Error } \\
\text { Mean }\end{array}$} & \multicolumn{2}{|c|}{$\begin{array}{l}95 \% \text { Confidence interval of } \\
\text { the Difference }\end{array}$} & & & \\
\hline & & & & Lower & Upper & & & \\
\hline Pir Pre Test- 1 Post Test & -4.679 & 1.478 & .409 & -5.694 & -3.890 & -11.393 & 16 & .000 \\
\hline
\end{tabular}

masih-masing anak. Bahkan terlihat secara nyata kepedulian anak dalam pembelajaran masih sangat kurang, anak tidak mendengarkan guru saat guru menjelaskan materi, mereka sibuk bermain dengan temen-temannya dan pada saat jam istirahat terlihat pula ada anak yang dikucilkan. Perilaku anak yang tidak mencerminkan semangat nasionalisme terlihat jelas saat kegiatan pre-test.

Berbeda halnya setelah anak mendapatkan perlakuan pembelajaran dengan menggunakan metode storytelling. Rasa simpati dan empati anak terhadap yang lain semakin membaik. Perilaku baik seperti saling menolong, bekerja sama dan mengatakan dengan jujur kepada guru dan teman. Perilaku seperti itu membutuhkan kontrol diri karena harus mengharuskan orang lain bersangkutan menekankan respon minat diri demi tindakan melayani kebutuhan oaring lain ${ }^{17}$.

Berdasarkan hasil wawancara, observasi dan hasil hitung uji-t, peneliti menyakini penggunaan metode storytelling dalam pembelajaran berdampak signifikan terhadap penanaman nilai-nilai karakter nasionalisme pada anak. Nilai-nilai nasionalisme itu meliputi lima aspek dalam Sila Pancasila yang diimplementasikan dalam segala aspek kehidupan sehari-hari yang tertuang dalam sila Ketuhanan yang Maha Esa, Kemanusiaan Yang Adil dan Beradab, Persatuan Indonesia, Kerakyatan yang Dipimpin oleh Hikmat Kebijaksanaan dalam Permusyawaratan Perwakilan, dan Keadilan Sosial Bagi Seluruh Rakyat Indonesia.

${ }^{17}$ John Janeway Conger, Perkembangan Dan Kepribadian Anak. Jakarta: Arcan, 1989,370)

\section{KESIMPULAN}

Berdasarkan hasil penelitian, dapat disimpulkan bahwa penggunakan metode storytelling berdampak signifikan dalam penanaman karakter nasionalisme siswa Kelas V SD Negeri Ngebel Kasihan Bantul. Perbedaaan tersebut terlihat selama proses pembelajaran yang mencakup lima pengamalan Pancasila yang diimplementasikan dalam kehidupan sehari-hari. Terdapat perubahan perilaku ke arah positif yang ditunjukan oleh siswa ketika menggunakan metode storytelling. Penanaman karakter nasionalisme pada siswa mulai terbentuk.

Wujud nyata yang muncul dapat proses penanaman karakter adalah melalui impelentasi Pancasila dalam keseharian siswa meliputi: siswa lebih tekun beribadah, kepeduliaan siswa akan pentingnya menjaga kesehatan diri dan lingkungan sekitar semakin baik, terbentuknya sikap kepedulian satu sama lain, adanya semangat toleransi yang tertanam pada siswa, tumbuhnya semangat kebersamaan, semakin besarnya kecintaan siswa terhadap tanah air, pengakuan akan kebinekatunggalikaan, pengambilan keputusan berdasarkan musyawarah, mengutamakan kepentingan bersama dibandingkan kepentingan pribadi, tidak adanya sikap diskriminatif, dan tumbuhnya semangat untuk saling membantu sesama.

\section{DAFTAR PUSTAKA}

Abdullah Munir. 2010. Pendidikan Karakter Membangun Karakter Anak Sejak dari Rumah. Yogyakarta: PT Pustaka Insan Madani

Apriani, A.N., \& Ariyani, Y.D. 2017. Analisis Muatan Nilai-Nilai Nasionalisme Pada Buku Teks KTSP Pkn Kelas 3 SD. Elementary School (Jurnal Pendidikan dan Pembelajaran Ke-SD-an), 4(2). 
Astiti, N., Rukayah, \& Sularmi. 2016. Peningkatan Keterampilan Menyimak Dongeng melalui Metode Storytelling. Diakses dari http://www.jurnal.fkip.uns. ac.id/index.p hp/

Ayuni, R.D., Siswati, \& Rusmawati, D. 2013. Pengaruh Storytelling Terhadap Perilaku Empati Anak. Jurnal Psikologi Undip, 12 (2), 121-130.

Budiyanto,Kabul.2007. Nilai-nilai Kepribadian Bangsa Indonesia. Bandung: Alfabeta.

Conger, John Janeway.1989. Perkembangan Dan Kepribadian Anak. Jakarta: Arcan

Dalyono, M. 2010. Psikologi Pendidikan. Jakarta: Rieneka Cipta.

Elmubarok, Zaim. 2008. Membumikan Pendidikan Nilai. Bandung: CV. Alfabeta

Hardjasoemantri, Koesnadi. 2000. Hukum TataLingkungan. Yogyakarta: Gadjah Mada UniversityPress.

Julita, D., Rubiantoro, Y., Susanto, T., \& Ahyar, R. F. 2012. Dongeng bentuk karakter anak. Warta PAUDNI, Tahun XV, edisi VII.
Koesoema, Dony. 2007. Pendidikan Karakter: Strategi Mendidik Anak di Zaman Global. Jakarta: PT. Grasindo, 2007.

Margono, S. 2005. Metodologi Penelitian Pendidikan. Jakarta: PT. Rineka Cipta.

Miftahuddin. 2008. Nasionalisme Indonesia: Nasionalisme Pancasila. Vol. 4 number 1, Januari 2008. Diakses di http://journal. uny.ac.id/index.php/ pada tanggal 03 Januari 2019 pukul 14.24 WIB.

Rukiyati, dkk. 2008. Pendidikan Pancasila. Yogyakarta. UNY Press.

Sofyan, H. 2011. Pendidikan Karakter dalam Perspektif Teori dan Praktik: Implementasi Pendidikan Karakter Melalui Kegiatan Mahasiswa. Yogyakarta: UNY Press.

Sugiyono. 2011. Metode Penelitian Kuantitatif, Kualitatif dan R\&D. Bandung: Afabeta

Syaodih, Ernawulan. 2005. Bimbingan di Taman Kanak-Kanak. Jakarta: Departemen Pendidikan Nasional. 